\title{
Characterization of Nutritional and Physico-chemical Properties of Parameria polyneura Hk.f.
}

\author{
Utpal Barua $^{1 *}$, R. P. Das ${ }^{1}$, R. K. Bhattacharyya ${ }^{1}$, Priyanka Das ${ }^{2}$, \\ R. N. Sarmah $^{3}$, K. Das ${ }^{4}$ and Bornali Gogoi ${ }^{1}$
}

${ }^{1}$ Department of Horticulture, ${ }^{2}$ Department of Biochemistry and Agricultural Chemistry,

${ }^{3}$ Department of Plant Breeding and Genetics, ${ }^{4}$ Department of Plant Physiology, Assam Agricultural University, Jorhat, Assam, India

*Corresponding author

\section{A B S T R A C T}

Keywords

Antioxidant,

Mineral,

Morphological

traits, Proximate

composition,

Underutilized,

Vitamins

Article Info

Accepted:

12 December 2020

Available Online:

10 January 2021
The present study documented the tree morphology, flowering and fruiting behaviour of Parameria polyneura. Biochemical profiling of fruits revealed the presence of moderate amount of crude fat $(0.53 \%)$, crude fibre $(1.81 \%)$, crude protein $(1.92 \%)$, carbohydrate $(92.41 \%)$, energy $(382.10 \mathrm{Kcal} 100 \mathrm{~g}$ $\left.{ }^{1}\right)$, total soluble sugar $(5.83 \%)$, reducing sugar $(3.12 \%)$, riboflavin (130.42 $\left.\mu \mathrm{g} \quad 100 \mathrm{~g}^{-1}\right)$ and thiamine $\left(20.15 \mu \mathrm{g} 100 \mathrm{~g}^{-1}\right)$. The fruits exhibited considerable antioxidant activities due to presence of ascorbic acid and phenol. Presence of macro and micro minerals such as phosphorous, sodium, potassium, calcium, magnesium, iron, manganese, copper and zinc signifies the nutritionally important value of the fruit.

\section{Introduction}

It has been estimated that at least one third of the people living in developing countries are affected by nutrient deficiencies (Mason et al., 2000). Fruits are a major source of nutrients such as fiber, minerals, vitamins and many phyto-chemicals that are good for preventing diseases (Deb, 1998). Mankind has been endowed with varieties of fruits, but only few gained popularity, considered nutritious and are being traded extensively. The fruits of endemic nature, which are wild, semi wild and underutilized due to lack of wider popularity but consumed with galore by the local inhabitants can also play an important role as food supplement. These fruits are known to possess all these essential elements like vitamins, minerals and polyphenols, etc. to compete with popular fruits. The antioxidant capacity of minor fruits may be comparable or even superior to that of 
the more extensively studied fruits. Besides these are integral parts of many enthno culture. In recent years, minor fruit species endemic to specific regions have been popular for intensive investigations (Abu Bakar et al., 2009).

'Mirika tenga' is one of the popular indigenous fruits of Assam. Kanjilal et al., (1934) identified this fruit species as Parameria polyneura $\mathrm{Hk}$. $\mathrm{f}$. belonging to the family Apocynaceae. Very little systematic effort has so far been made for improvement of this crop. Before the initiation of programme of any crop, it is essential to generate information on morphological parameters. Moreover very less systematic approach has so far been made to study the nutritional aspects of this fruit. Hence, a study was conducted covering all these aspects so that it could help nutritionist, processing industry and breeders in their own fields.

\section{Materials and Methods}

\section{Plant material}

Five healthy bearing Parameria polyneura of 10-12 year age were identified and selected in five locations of Jorhat $\left(26^{\circ} 40^{\prime} \mathrm{N}, 94^{\circ} 60^{\prime} \mathrm{E}\right.$, altitude $88 \mathrm{~m})$ and Sibsagar $\left(26^{\circ} 91^{\prime} \mathrm{N}\right.$, $94^{\circ} 73^{\prime} \mathrm{E}$, altitude $92 \mathrm{~m}$ ) district of Assam, India. The selected trees were growing in homestead area of villages. The morphological data were recorded during the growth period in the field condition and were recorded in four replicates. The fruit were harvested from the plant considering the optimum time of fruit maturity judged by the findings of Neog (1990). Collected fruit samples were fresh, matured, well shaped and free from pests, diseases and other organoleptic deterioration. The freshly collected sample was washed with deionised water to eliminate visible dart and removed water quickly with a blotting paper. Then the samples were cut into small pieces, homogenized and accurate amount was weighed as required for fresh analysis and remaining was oven dried for further analysis on dry weight basis and stored in air tight container in dehumidifier.

\section{Environmental condition}

The climatic condition of the experimental site was sub-tropical hot humid summer followed by relatively dry and cold winter. The mean annual maximum temperature (July to August) lies between $32^{\circ} \mathrm{C}$ to $33^{\circ} \mathrm{C}$, while the minimum ranges from $9^{\circ} \mathrm{C}$ to $12^{\circ} \mathrm{C}$ (December to January). The average rainfall is about $1900 \mathrm{~mm}$, humidity varies from 74 to 87 per cent.

\section{Morphological characters of the plants}

The plant type, tree shape, phyllotaxy and leaf shape was determined by the growth habit of the plant by following minimal descriptor prepared by NBPGR, New Delhi (Mahajan et al., 2002). Ten fully expanded green leaves were collected from each tree. The leaf area and perimeter of each leaf was measured with a Systronics - 211 leaf area meter (Make CID, Inc., USA). The duration of 50 per cent flowering was recorded during the period when more than 50 per cent flowers of the tree opened. The date for the first and last flower appearance was noted for recording the duration of flowering season. The flowering phenology like anthesis was studied following method of Mathur and Mohan Ram (1986).

\section{Physical parameters of fruit}

Four branches having flowers of same age group were tagged with numbered metallic labels after anthesis. Fruit samples were collected at appropriate maturity stage. The days between date of petal fall and swelling 
of ovary to the date of harvest was calculated as duration for fruit maturity. The edible portion of whole fruit was determined by subtracting the weight of inedible parts (e.g. skin and seed) of fruits from the weight of whole fruits.

\section{Determination of chemical constituents of leaf and fruit}

Total chlorophyll content of leaves was estimated by the method of Witham et al. (1971). Moisture content of the edible part of fruit was determined by using the method of A.O.A.C. (1965) and was expressed in percentage on fresh weight basis. Titrable acidity was estimated by using standard method of A.O.A.C. (1980) and was expressed in percentage of anhydrous citric acid. Reducing sugar was estimated following the 3, 5-dinitrosalicylic acid (DNS) method of Miller (1972). The total soluble sugar was estimated colorimetrically by Anthrone method of Hedge and Hofreiter (1962). Total nitrogen was determined by Micro-Kjeldahl's method described by Humphries (1956). Nitrogen was estimated as the amount of ammonia evolved during steam distillation of the digest.

The amount of nitrogen was expressed as percentage on dry weight basis. The crude protein was estimated on dry weight basis by multiplying the total nitrogen value with the factor 6.25. The crude fat as ether extract was determined from oven dried sample using a Soxhlet extraction apparatus (A.O.A.C., 1980). Crude fiber was estimated by the method as described by Maynard (1970). Total ash content was estimated by following the method of A.O.A.C. (1965). Total carbohydrate on dry weight basis was determined by the following equation (Gopalan et al., 1989). The gross food energy was estimated (Osborn and Voogt, 1978) and expressed as Kcal/100 g dry basis. The pectin was estimated by gravimetric method as described by Ranganna, 1979, measured pectin content as calcium pectate. The total phenol estimation was carried out with FolinCiocalteu reagent (FCR) following the method described by Bray and Thorpe (1954). The amount of phenol present in the sample was calculated from the standard curve prepared by using different concentrations of catechol and expressed as mg phenols/100 g material.

\section{Water soluble vitamins}

The ascorbic acid content was determined by direct colorimetric method using 2, 6dichlorophenol-indophenol as described by Loeffler and Ponting (1942). While thiamine content was estimated by following fluorormetric method described by Hennessy and Cerecedo (1939). Riboflavin content was estimated by fluorometric method described by Hodson and Norris (1939).

\section{Nutritionally important minerals}

The phosphorous content of dry fruit samples were estimated by wet digestion method. The samples were extracted by di-acid mixture $\left(\mathrm{HNO}_{3}: \mathrm{HClO}_{4}\right.$ 2:5 ratio) and estimated by vanadomolybdate method (Baruah and Borthakur, 1997) and was expressed as percentage. The potassium and sodium content of dry fruit samples were determined by the flame photometric method described by Jackson (1973) and was expressed as percentage. The calcium and magnesium content were estimated by EDTA method (Jackson, 1973). The nutrients such as iron, manganese, copper and zinc content of the dry fruit samples were estimated in Chemito Double Beam Atomic Absorption Spectrophotometer (AA 203D) taking aliquots from di-acid digestion mixture (Baruah and Borthakur, 1997). 


\section{Total antioxidant activities}

The antioxidant activity was determined by the method given by Molyneux (2004). Free radical scavenging ability of DPPH $(1,1-$ diphenyl-2-picrylhydrazyl) was determined on methanolic extracts of dried fruit samples. A decreasing intensity of the purple colouration was taken as increasing scavenging activity. Antioxidant activity of Lascorbic acid and quercetin were also assayed as standard. The inhibition of DPPH radicals by the sample was calculated as -

DPPHinhibition $(\%)=\frac{\text { Absorbance of control }- \text { Absorbance of sample }}{\text { Absorbance of control }} \times 100$

The amount of sample necessary to decrease the absorbance of DPPH by 50 per cent i.e. $\mathrm{IC}_{50}$ was derived from the per cent disappearance vs. concentration plot.

\section{Statistical analysis}

The statistical analysis for each character was carried out on mean values. The data were subjected to analysis of variance as described by Panse and Sukhatme (1985). The level of significance used in ' $\mathrm{F}$ ' and ' $\mathrm{T}$ ' test was $\mathrm{P}=$ 0.05 . Critical Difference (CD) value was calculated wherever ' $F$ ' test was found significant.

\section{Results and Discussion}

\section{Morphology}

In the present investigation it was observed that, Parameria polyneura Hk. f. is an evergreen slender woody climbing shrub with irregular shape (Fig 1). Leaves are simple, elliptic, arranged with alternate phyllotaxy (Fig 2), silvery white in lower surface with dark green colour in upper surface (Fig 3). The flowers are borne on the leaf axils on current season's growth, hermaphrodite racemes, four lobed with single perianth (Fig
4 and 5). The fruit is drupe, oblong to cylindrical round in shape with reddish colour at the time of ripening and single seeded (Fig 6 and 7). No variations were observed in these characters among the studied plants under different locations. Neog (1990) reported similar morphology in Parameria polyneura.

The analysis of variance revealed the presence of significant variation for most of the characters among the studied plants under different locations. The different leaf and flower characters of Parameria polyneura are presented in Table 1. Significant variation was recorded among the different plants for leaf length. The mean value for leaf length, leaf breadth, leaf area, leaf perimeter and total chlorophyll content was found to be $15.38 \pm 0.035 \mathrm{~cm}, 7.36 \pm 0.032 \mathrm{~cm}, 83.06 \pm 0.398$ $\mathrm{cm}^{2}, 35.67 \pm 0.082 \mathrm{~cm}$ and $0.97 \pm 0.012 \mathrm{mg} \mathrm{g}^{-1}$ respectively. Significant variation was observed for flowering characters among the studied plants.

The mean values for 50 percent flowering, flowering duration, inflorescence length, flower length and flower breadth was recorded to be $5.50 \pm 0.141$ days, $27.55 \pm 0.311$ days, $1.49 \pm 0.025 \mathrm{~cm}, 0.67 \pm 0.015 \mathrm{~cm}$ and $0.95 \pm 0.014 \mathrm{~cm}$ respectively. In general, the flowering began from $22^{\text {nd }}$ December and ended on $18^{\text {th }}$ January, while duration of 50 per cent flowering commenced in between $2^{\text {nd }}$ January to $8^{\text {th }}$ January.

Similar results were reported by Neog (1990) and Neog and Kalita (1994) in Parameria polyneura from Assam. The anthesis lasted for minimum 1.45 hours in PP-1 (5.30 A.M.7.15 A.M.) and PP-2 (5.15 A.M.-7.00 A.M.), while it lasted for 2.30 hours (5.00 A.M.-7.30 A.M.) in PP-4. The results are in conformity with the findings of Neog and Kalita (1994). The time of anthesis is dependent on temperature and relative humidity. 
Table.1 Leaf and flower characters of Parameria polyneura

\begin{tabular}{|c|c|c|c|c|c|c|c|c|c|c|c|}
\hline Accessions & $\begin{array}{c}\text { Leaf } \\
\text { length } \\
(\mathrm{cm})\end{array}$ & $\begin{array}{c}\text { Leaf } \\
\text { breadth } \\
(\mathrm{cm})\end{array}$ & $\begin{array}{l}\text { Leaf } \\
\text { area } \\
\left(\mathrm{cm}^{2}\right)\end{array}$ & $\begin{array}{l}\text { Leaf } \\
\text { perimeter } \\
(\mathrm{cm})\end{array}$ & $\begin{array}{c}\text { Total } \\
\text { chlorophyll } \\
(\mathbf{m g} / \mathrm{g})\end{array}$ & $\begin{array}{c}\text { Duration of } \\
50 \% \\
\text { flowering } \\
\text { (days) }\end{array}$ & $\begin{array}{l}\text { Duration of } \\
\text { flowering } \\
\text { (days) }\end{array}$ & $\begin{array}{l}\text { Inflorescence } \\
\text { length }(\mathbf{c m})\end{array}$ & $\begin{array}{c}\text { Flower } \\
\text { length } \\
(\mathrm{cm})\end{array}$ & $\begin{array}{l}\text { Flower } \\
\text { breadth } \\
\text { (cm) }\end{array}$ & Anthesis \\
\hline PP-1 & 15.29 & 7.46 & 82.75 & 35.65 & 0.97 & 5.75 & 26.75 & 1.51 & 0.67 & 0.92 & $\begin{array}{l}\text { 5.00 A.M.- } \\
\text { 7.00 A.M. }\end{array}$ \\
\hline PP-2 & 15.20 & 7.01 & 80.83 & 34.57 & 0.93 & 5.25 & 26.75 & 1.64 & 0.62 & 0.91 & $\begin{array}{l}\text { 5.30 A.M.- } \\
\text { 7.15 A.M. }\end{array}$ \\
\hline PP-3 & 15.46 & 7.49 & 83.93 & 35.70 & 0.95 & 5.50 & 28.25 & 1.40 & 0.66 & 0.96 & $\begin{array}{l}\text { 5.15 A.M.- } \\
\text { 7.00 A.M. }\end{array}$ \\
\hline PP-4 & 15.37 & 7.28 & 82.96 & 36.56 & 0.99 & 5.00 & 27.50 & 1.36 & 0.67 & 0.97 & $\begin{array}{l}\text { 5.00 A.M.- } \\
\text { 7.30 A.M. }\end{array}$ \\
\hline PP-5 & 15.59 & 7.57 & 84.82 & 35.87 & 1.00 & 6.00 & 28.50 & 1.54 & 0.73 & 1.00 & $\begin{array}{l}\text { 5.00 A.M.- } \\
\text { 7.00 A.M. }\end{array}$ \\
\hline Mean & 15.38 & 7.36 & 83.06 & 35.67 & 0.97 & 5.50 & 27.55 & 1.49 & 0.67 & 0.95 & \\
\hline S.Ed. ( \pm$)$ & 0.035 & 0.032 & 0.398 & 0.082 & 0.012 & 0.141 & 0.311 & 0.025 & 0.015 & 0.014 & \\
\hline $\mathrm{CD}_{(0.05)}$ & 0.076 & 0.069 & 0.868 & 0.178 & 0.026 & 0.307 & 0.678 & 0.055 & 0.032 & 0.031 & \\
\hline
\end{tabular}

Table.2 Physical parameters of fruit and seed

\begin{tabular}{|c|c|c|c|c|c|c|c|c|c|c|c|}
\hline Accessions & $\begin{array}{c}\text { Duration } \\
\text { of fruit } \\
\text { maturity } \\
\text { (days) }\end{array}$ & $\begin{array}{l}\text { Fruit } \\
\text { length } \\
\text { (cm) }\end{array}$ & $\begin{array}{c}\text { Fruit } \\
\text { breadth } \\
\text { (cm) }\end{array}$ & $\begin{array}{c}\text { Fruit } \\
\text { weight } \\
\text { (g) }\end{array}$ & $\begin{array}{c}\text { Fruit } \\
\text { volume } \\
\text { (cc) }\end{array}$ & $\begin{array}{c}\text { Edible } \\
\text { portion } \\
(\%)^{*}\end{array}$ & $\begin{array}{c}\text { Seed } \\
\text { number }\end{array}$ & $\begin{array}{c}\text { Seed } \\
\text { length } \\
(\mathrm{cm})\end{array}$ & $\begin{array}{c}\text { Seed } \\
\text { breadth } \\
(\mathrm{cm})\end{array}$ & $\begin{array}{c}\text { Seed } \\
\text { weight } \\
\text { (g) }\end{array}$ & $\begin{array}{c}\text { Seed } \\
\text { volume } \\
\text { (cc) }\end{array}$ \\
\hline PP-1 & 70.00 & 3.89 & 2.98 & 13.29 & 14.98 & 81.65 & 1.00 & 3.17 & 1.26 & 2.13 & 2.06 \\
\hline PP-2 & 72.40 & 3.73 & 2.81 & 13.06 & 14.89 & 81.43 & 1.00 & 3.34 & 1.33 & 2.30 & 2.19 \\
\hline PP-3 & 71.25 & 3.82 & 2.84 & 13.09 & 14.56 & 81.68 & 1.00 & 3.40 & 1.38 & 2.31 & 2.21 \\
\hline PP-4 & 65.25 & 3.70 & 2.61 & 12.96 & 14.78 & 81.33 & 1.00 & 3.44 & 1.37 & 2.16 & 2.11 \\
\hline PP-5 & 68.75 & 3.66 & 2.57 & 12.83 & 14.54 & 81.26 & 1.00 & 3.49 & 1.48 & 2.45 & 2.31 \\
\hline Mean & 69.53 & 3.76 & 2.76 & 13.05 & 14.75 & 81.47 & 1.00 & 3.37 & 1.36 & 2.27 & 2.18 \\
\hline S.Ed. ( \pm$)$ & 1.062 & 0.011 & 0.017 & 0.032 & 0.031 & 0.025 & NS & 0.026 & 0.026 & 0.038 & 0.014 \\
\hline $\mathrm{CD}_{(0.05)}$ & 2.314 & 0.025 & 0.038 & 0.069 & 0.068 & 0.055 & NS & 0.056 & 0.057 & 0.083 & 0.030 \\
\hline
\end{tabular}


Table.3 Proximate composition and energy value of Parameria polyneura fruit

\begin{tabular}{|c|c|c|c|c|c|c|c|}
\hline Accessions & $\begin{array}{c}\text { Moisture } \\
\text { content }(\%) *\end{array}$ & $\begin{array}{c}\text { Total ash } \\
\text { content }(\%)^{* * *}\end{array}$ & $\begin{array}{l}\text { Crude fat } \\
(\%)^{* *}\end{array}$ & $\begin{array}{c}\text { Crude } \\
\text { fibre } \\
(\%)^{* *}\end{array}$ & $\begin{array}{l}\text { Crude protein } \\
(\%)^{* *}\end{array}$ & $\begin{array}{c}\text { Total } \\
\text { carbohydrate } \\
(\%)^{* *}\end{array}$ & $\begin{array}{c}\text { Energy } \\
\text { (Kcal/ 100g) }\end{array}$ \\
\hline PP-1 & 89.78 & 3.45 & 0.52 & 1.85 & 1.95 & 92.24 & 381.41 \\
\hline PP-2 & 88.69 & 3.28 & 0.58 & 1.92 & 1.88 & 92.35 & 382.07 \\
\hline PP-3 & 88.72 & 3.38 & 0.48 & 1.79 & 1.90 & 92.46 & 381.70 \\
\hline PP-4 & 87.55 & 3.36 & 0.56 & 1.74 & 1.91 & 92.44 & 382.40 \\
\hline PP-5 & 87.53 & 3.19 & 0.53 & 1.75 & 1.99 & 92.55 & 382.93 \\
\hline Mean & 88.45 & 3.33 & 0.53 & 1.81 & 1.92 & 92.41 & 382.10 \\
\hline S.Ed. $( \pm)$ & 0.235 & 0.033 & 0.008 & 0.017 & 0.007 & 0.041 & 0.139 \\
\hline $\mathrm{CD}_{(0.05)}$ & 0.511 & 0.071 & 0.017 & 0.038 & 0.016 & 0.088 & 0.303 \\
\hline
\end{tabular}

* Fresh weight basis

** Dry weight basis

Table.4 Some important biochemical parameters of Parameria polyneura fruit

\begin{tabular}{|c|c|c|c|c|c|c|c|c|c|c|c|}
\hline Accessions & pH & $\begin{array}{l}\text { TSS } \\
\left({ }^{\circ} \mathbf{B}\right)\end{array}$ & $\begin{array}{c}\text { Pectin } \\
(\%)^{*}\end{array}$ & $\begin{array}{c}\text { Titrable } \\
\text { acidity } \\
(\%)^{*}\end{array}$ & $\begin{array}{c}\text { TSS- } \\
\text { acidity } \\
\text { ratio }\end{array}$ & $\begin{array}{c}\text { Total } \\
\text { soluble } \\
\text { sugar } \\
(\%)^{* *}\end{array}$ & $\begin{array}{l}\text { Reducing } \\
\text { sugar } \\
(\%) * *\end{array}$ & $\begin{array}{c}\text { Non } \\
\text { reducing } \\
\text { sugar } \\
(\%)\end{array}$ & $\begin{array}{c}\text { Sugar- } \\
\text { acidity } \\
\text { ratio }\end{array}$ & $\begin{array}{c}\text { Riboflavin } \\
(\mu \mathrm{g} / 100 \mathrm{~g}) \\
* *\end{array}$ & $\begin{array}{c}\text { Thiamine } \\
(\mu \mathrm{g} / 100 \mathrm{~g}) \\
* *\end{array}$ \\
\hline PP-1 & 3.08 & 9.47 & 1.17 & 3.09 & 3.07 & 6.00 & 3.22 & 2.78 & 1.94 & 130.32 & 20.13 \\
\hline PP-2 & 3.22 & 9.14 & 1.11 & 3.22 & 2.84 & 5.81 & 3.21 & 2.59 & 1.80 & 130.89 & 19.45 \\
\hline PP-3 & 3.18 & 9.21 & 1.05 & 3.17 & 2.91 & 5.75 & 3.13 & 2.62 & 1.81 & 130.21 & 20.58 \\
\hline PP-4 & 3.20 & 9.45 & 1.08 & 3.14 & 3.01 & 5.89 & 3.08 & 2.81 & 1.88 & 130.13 & 20.33 \\
\hline PP-5 & 3.13 & 9.31 & 1.12 & 3.18 & 2.93 & 5.69 & 2.97 & 2.73 & 1.79 & 130.53 & 20.25 \\
\hline Mean & 3.16 & 9.31 & 1.11 & 3.16 & 2.95 & 5.83 & 3.12 & 2.71 & 1.85 & 130.42 & 20.15 \\
\hline S.Ed. ( $( \pm)$ & 0.012 & 0.029 & 0.012 & 0.019 & 0.024 & 0.045 & 0.031 & NS & 0.023 & 0.090 & 0.163 \\
\hline $\mathrm{CD}_{(0.05)}$ & 0.025 & 0.062 & 0.025 & 0.042 & 0.051 & 0.098 & 0.067 & NS & 0.051 & 0.197 & 0.356 \\
\hline
\end{tabular}

* Fresh weight basis

** Dry weight basis 
Table.5 Ascorbic acid, total phenol, total antioxidant capacity and $\mathrm{IC}_{50}$ value of Parameria polyneura fruit

\begin{tabular}{|c|c|c|c|c|}
\hline Accessions & $\begin{array}{c}\text { Ascorbic acid (mg/100 } \\
\text { g)* }\end{array}$ & $\begin{array}{l}\text { Total phenol } \\
(\mathrm{mg} / 100 \mathrm{~g})^{* *}\end{array}$ & $\begin{array}{c}\text { TAC (\%) per mg } \\
\text { sample*** }\end{array}$ & $\begin{array}{l}\mathrm{IC}_{\mathbf{5 0}} \text { value } \\
(\mathrm{mg} / \mathrm{ml})^{* *}\end{array}$ \\
\hline PP-1 & 6.04 & 0.61 & 8.54 & 5.85 \\
\hline PP-2 & 5.83 & 0.55 & 8.44 & 5.93 \\
\hline PP-3 & 5.77 & 0.53 & 8.34 & 6.00 \\
\hline PP-4 & 5.88 & 0.57 & 8.30 & 6.02 \\
\hline PP-5 & 5.73 & 0.53 & 8.26 & 6.06 \\
\hline Mean & 5.85 & 0.56 & 8.37 & 5.97 \\
\hline S.Ed. $( \pm)$ & 0.017 & 0.008 & 0.011 & 0.008 \\
\hline $\mathrm{CD}_{(0.05)}$ & 0.036 & 0.016 & 0.024 & 0.017 \\
\hline Ascorbic acid & & & & 0.051 \\
\hline Quercetin & & & & 0.052 \\
\hline
\end{tabular}

* Fresh weight basis

** Dry weight basis

Table.6 Some important mineral composition (on dry weight basis) of Parameria polyneura fruit

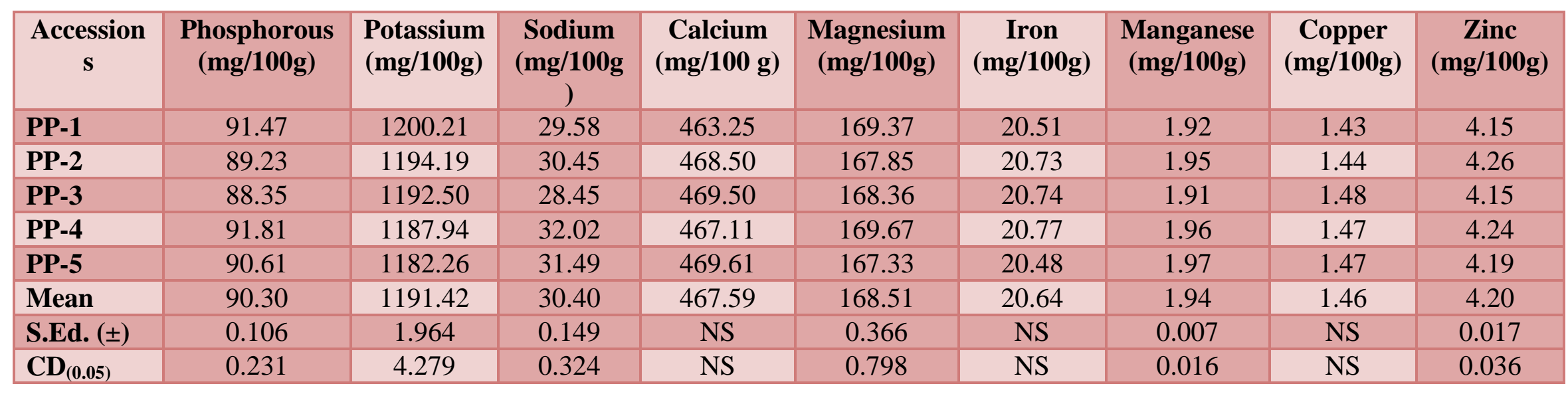




\section{Fig}

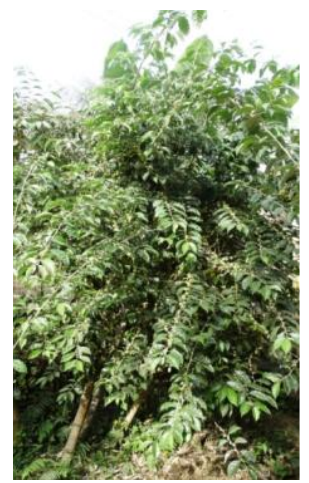

Fig. 1 Parameria polyneura tree

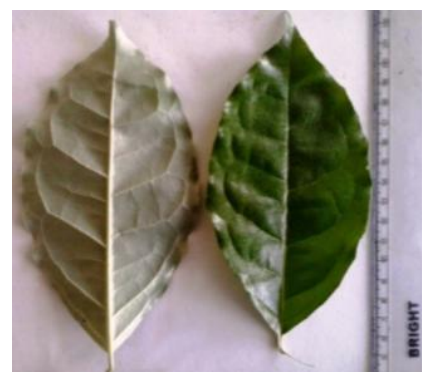

Fig. 3 Parameria polyneura leaf shape and size

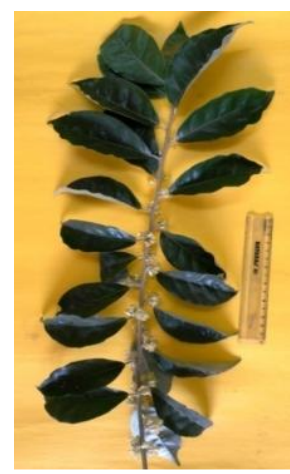

Fig. 2 Parameria polyneura phyllotaxy

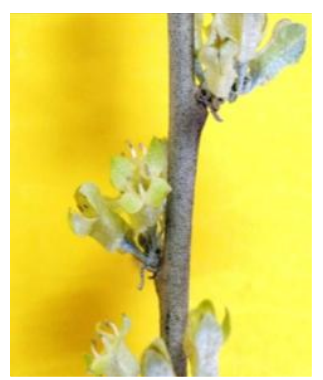

Fig. 4 Parameria polyneura inflorescence

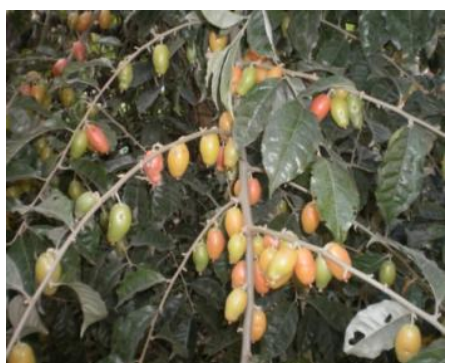

Fig. 6 Parameria polyneura fruit on tree
Fig. 5 Parameria polyneura flower
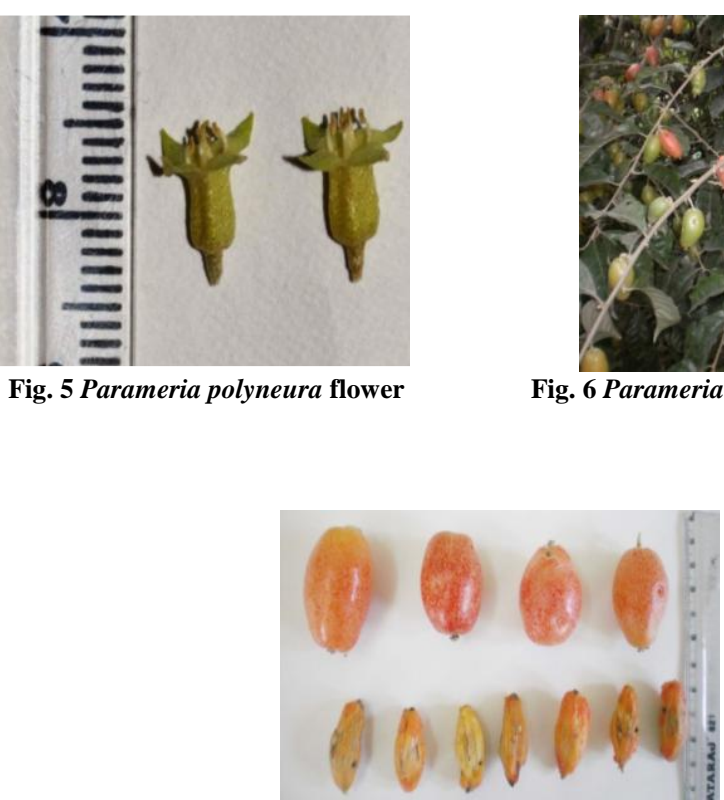

Fig. 7 Parameria polyneura fruit and seed 
The different physical parameters of fruit and seed are presented in Table 2. The mean values for duration for fruit maturity, fruit length, fruit breadth, fruit weight, fruit volume and edible portion was recorded to be $69.53 \pm 1.062$ days, $3.76 \pm 0.011 \mathrm{~cm}$, $2.76 \pm 0.017 \mathrm{~cm}, \quad 13.05 \pm 0.032 \mathrm{gm}$, $14.75 \pm 0.031 \mathrm{cc}$ and $81.47 \pm 0.025$ per cent respectively. Parameria polyneura is a single seeded fruit. Seed characters also exhibited significant variations among their physical characters. The average seed length, seed breadth, seed weight and seed volume was measured to be $3.37 \pm 0.26 \mathrm{~cm}, 1.36 \pm 0.026 \mathrm{~cm}$, $2.27 \pm 0.038 \mathrm{gm}$ and $2.18 \pm 0.014 \mathrm{cc}$ respectively. Similar types of results were also reported by Neog (1990) and Neog et al. (2001).

Leaf, flower, fruit and seed characters are the yield contributing traits. It can directly influence the yield of a fruit crop. The study has given an insight to the presence of variability for these parameters among the studied accessions. Further studies coupled with more number of investigations and statistical procedures would help to find out superior genotypes. The estimation of chlorophyll content is helpful to understand the process of source and sink relationship, which has a direct or indirect effort on fruit production. Puzari and Hazarika, (2001), opined that the dark green coloured leaves are found to contain higher total chlorophyll as compared to pale green coloured leaves.

\section{Proximate composition of fruit}

The proximate composition and energy value of Parameria polyneura fruit are presented in Table 3. Among the studied accessions, moisture content of fresh fruit ranged between 87.53-89.78 per cent with an average of $88.45 \pm 0.235$ per cent. Neog, 1990 and Neog et al., 2001 also reported almost similar type of moisture content. Significant variations were exhibited by the studied accessions for total ash, crude fat, crude fibre, crude protein, total carbohydrate and energy. The mean values recorded were $3.33 \pm 0.033$ per cent, $0.53 \pm 0.008$ per cent, $1.81 \pm 0.017$ per cent, $1.92 \pm 0.007$ per cent, $92.41 \pm 0.041$ per cent and $382.10 \pm 0.139$ Kcal $100 \mathrm{~g}^{-1}$ fruit respectively. The presence of low fat, high carbohydrate and energy indicates the high calorific value of the fruit.

\section{Biochemical composition fruit}

Some important parameters regarding biochemical composition of Parameria polyneura fruit are presented in Table 4 . The average value of $\mathrm{pH}$, TSS, titratable acidity, TSS acidity ratio, total soluble sugar, reducing sugar and sugar acidity ration recorded was $3.16 \pm 0.012,9.31 \pm 0.029{ }^{\circ} \mathrm{B}$, $3.16 \pm 0.019$ per cent, $2.95 \pm 0.024,5.83 \pm 0.045$ per cent, $3.12 \pm 0.031$ per cent and $1.85 \pm 0.023$ respectively. Neog (1990) and Neog et al., (2001) also reported similar trend of result in Parameria polyneura. The mean values for non reducing sugar, pectin content, riboflavin and thiamine was found to be $3.12 \pm 0.031$ per cent, $1.11 \pm 0.012$ per cent, $130.42 \mu \mathrm{g} 100 \mathrm{~g}^{-1}$ and $20.15 \mu \mathrm{g} 100 \mathrm{~g}^{-1}$ respectively. The presence of more acidity and low sugar indicates the suitability of this fruit for pickle making. The presence of riboflavin and thiamine will sure be added advantage to include value added products of this fruit to fight malnourishment.

\section{Ascorbic acid, total phenol content and total antioxidant capacity}

The ascorbic acid, total phenol and total antioxidant capacity of Parameria polyneura fruit are presented in Table 5. The range of ascorbic acid content was found to be 5.73$6.04 \mathrm{mg} 100 \mathrm{~g}^{-1}$ with an average value of $5.85 \pm 0.017 \mathrm{mg} 100 \mathrm{~g}^{-1}$ fruit. The results are in conformity with the findings of Neog (1990). 
Yingthongchai et al., (2013) opined that, difference ascorbic acid content may be attributed to climatic condition, cultural practices and fruit maturity at harvest. The significant variation was recorded for total phenol content and mean value recorded was $0.56 \pm 0.008 \mathrm{mg} 100 \mathrm{~g}^{-1}$. The mean value of total antioxidant capacity $(\%)$ and $\mathrm{IC}_{50}$ value through DPPH inhibition per mg dry fruit sample was found to be $8.37 \pm 0.011$ per cent and $5.97 \pm 0.008 \mathrm{mg} \mathrm{ml}^{-1}$ respectively. The presence of ascorbic acid and phenol in the fruit samples has enhanced the antioxidant capacity of the fruit. It signifies that the fruit can be used for preparation of nutraceuticals.

\section{Mineral composition}

Some important mineral compositions are presented in Table 6. There has not been much documentation on the mineral composition of Parameria polyneura fruits. A attempt was made to find out the presence of macro and micro minerals. Among the studied accessions, significant variations were observed for phosphorous, potassium, sodium, magnesium, manganese and zinc. The mean values for these macro and micro minerals were $90.30 \pm 0.106 \mathrm{mg} 100 \mathrm{~g}^{-1}$, $1191.42 \pm 1.964{\mathrm{mg} 100 \mathrm{~g}^{-1}, 30.40 \pm 0.149 \mathrm{mg}}$ $100 \mathrm{~g}^{-1}, 168.51 \pm 0.366 \mathrm{mg} 100 \mathrm{~g}^{-1}, 1.94 \pm 0.007$ $\mathrm{mg} 100 \mathrm{~g} \mathrm{~g}^{-1}$ and $4.20 \pm 0.017 \mathrm{mg} 100 \mathrm{~g}^{-1}$ respectively. Non significant variations were observed for calcium, iron and copper. Their mean values were $467.59 \mathrm{mg} 100 \mathrm{~g}^{-1}, 20.64$

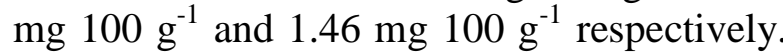
The study revealed that the Parameria polyneura fruit is loaded with good amount of macro and micro nutrients. Sodium and potassium takes part in ionic balance of the human body in maintaining tissue excitability. Sodium plays important role in the transport of metabolites and potassium is important for its diuretic nature. Calcium constitutes a large proportion of the bone and human blood. Copper is another trace element essential in human body. Zinc is a cofactor for a number of enzymes. Iron and Manganese are essential for haemoglobin formation. The functions of these minerals are well known and have been proved by many studies. Shukri et al. (2013) opined that the mineral composition of minor fruit may vary due to several factors such as fruit maturity, climate, soil type, fertility and agricultural practices.

In conclusion the present investigation has showed that Parameria polyneura fruit are loaded with many nutrients and minerals. The presence of more fibre, protein, carbohydrate, energy, TSS, riboflavin, thiamine, ascorbic acid, macro an micro minerals makes this fruit not only suitable for inclusion in the dietary plans for rural masses but also processing and value addition to cater the needs of urban population. There by it can help to generate small and micro industries for societal upliftment and employment generation. The presence of phenols and higher antioxidant capacity makes this fruit suitable for nutraceuticals. The documentation on morphological characters would help researchers to exploit the variability present in the gene pool for further detailed studies and selecting superior types for varietal establishment. Further research is required to explore this and other lesser known tropical minor fruits in order to reduce our dependency on the relatively few fruits that are being cultivated at present.

\section{Acknowledgements}

The corresponding author is grateful to the Director, ICAR for North Eastern Hill Region, Umiam, Meghalaya for granting study leave permission leading to $\mathrm{Ph} . \mathrm{D}$.

\section{References}

Abu Bakar, M.F., Mohamed, M., Rahmat, A., Fry, J. 2009. Phytochemicals and 
antioxidant activity of different parts of bambangan (Mangifera pajang) and tarap (Artocarpus odoratissimus). Food Chem., 113: 479-483.

A.O.A.C., 1965. Official Methods of Analysis, $10^{\text {th }}$ Edn. Association of Official Agricultural Chemists, Washington, DC.

A.O.A.C., 1980. Official Methods of Analysis, $13^{\text {th }}$ Edn. Association of Official Analytical Chemists, Washington, D.C.

Baruah, T.C., Borthakur, H.P., 1997. A Text Book of Soil Analysis. Vikas Publishing House Pvt. Ltd., New Delhi.

Bray, H.G., Thorpe, W.V., 1954. Analysis of phenolic compounds of interest in metabolism. Methods Biochem Anal., 1: 27-52.

Deb, A.C., 1998. Fundamentals of biochemistry. $7^{\text {th }}$ ed., New Central Book Agency (P) Ltd., Calcutta, India.

Gopalan, C., Ram Sastri, B.V., Balasubramaniam, S.C., 1989. Nutritive value of Indian foods. $2^{\text {nd }} E d n$., National Institute of Nutrition, ICMR, Hyderabad.

Hedge, J.E., Hofreiter, B.T., 1962. In: Carbohydrates Chemistry. Whistler, R.L. and BeMiller, J.N. (Eds.), Academic Press, New York.

Hennessy, D.J., Cerecedo, L.R., 1939. The determination of free and phosphorylated thiamine by a modified thiochrome assay. J. American Chem. Soc., 61:179-183.

Hodson, A.Z., Norris, L.C., 1939. A fluorometric method for determining the riboflavin content of foodstuffs. J. Biol. Chem., 131:621-630.

Humphries, E.C., 1956. Modern methods of plant analysis. Springer-Verlag, Berlin.

Jackson, M.L., 1973. Soil chemical analysis. Prentice Hall of India Pvt. Ltd., New Delhi.

Kanjilal, U.N., Kanjilal, P.C., Das, A., 1934.
Flora of Assam, Vol. I., Govt. of Assam. Loeffler, H.J., Ponting, J.D., 1942. Ascorbic acid, a rapid determination in fresh, frozen or dehydrated fruits and vegetables. Ind. Eng. Chem. Anal. Edn., 14: 846-848.

Mahajan, R.K., Gangopadhyay, K.K., Kumar, G., Dobhal, V.K., Srivastava, U., Gupta, P.N., Pareek, S.K., 2002. Minimal descriptors of agri-horticutural crops, Part III: Fruit Crops. National Bureau of Plant Genetic Resources, New Delhi.

Mason, J.B., Lotfi, M., Dalmiy, N., Sethuraman, K., Deitchler, M., Geibel, S., Gillenwate K., Gilman, A., Maso, K., Mock, N., 2000. The micronutrient report: current progress in the control of vitamin $\mathrm{A}$, iodine and iron deficiencies. Med., 160(1): 931-936.

Mathur, G., Mohan Ram, H.Y., 1986. Floral biology and pollination of Lantana camera. Phytomorph., 36: 79-100.

Maynard, A.J., 1970. Methods in food analysis. Academic press, New York.

Miller, G.L., 1972. Use of dinitrosalicylic acid reagent for determination of reducing sugar. Analytical Chem., 31(3): 426-428.

Molyneux, P., 2004. The use of the stable free radical diphenylpicrylhydrazyl (DPPH) for estimating antioxidant activity. Songklanakarin J. Sci. Technol., 26(2): 211-219.

Neog, M., 1990. Studies on the floral biology, growth and development of few minor fruits of Assam. M.Sc. Thesis, Assam Agricultural University, Jorhat.

Neog, M., Kalita, P., 1994. A note on the floral biology of mirika-tenga (Parameria polyneura HK.f.). The Hort. J., 7(1): 55-58.

Neog, M., Mohan, N.K., Chakraborty, B.K., 2001. Physico-chemical changes during growth and development of Mirikatenga (Parameria polyneura HK.f.) fruit. The Hort. J., 14(2): 121-126. 
Osborn, D.R., Voogt., 1978. Calculation of calorific value. In: The Analysis of Nutrients in Foods. Academic Press, New York.

Panse, V.S., Sukhatme, P.V., 1985. Statistical methods for agricultural workers, $4^{\text {th }}$ Edn. ICAR, New Delhi.

Puzari, N.N., Hazarika, $\quad$ B.N., 2001. Chlorophyll estimation in some minor fruit crops. Adv. Plant Sci. 14(1): 295296.

Ranganna, S., 1979. Manual of analysis of fruit and vegetable products. Tata McGraw Hill Publishing Co. Ltd., New Delhi.

Shukri, M.A.M., Mirfat, A.H.S., Sabrina,
M.N.E., Razali, M., Salma, I., 2013. Nutritional value and potential of Malaysian underutilized fruits and traditional vegetables. Acta Hort., 979: 173-185.

Witham, F.H., Blaydes, D.F., Devlin, R.M. 1971. Experiments in plant physiology, Van Nostrand, New York.

Yingthongchai, P., Naphrom, D., Smitamana, P., (2013). Study on some characteristics of Elaeagnus latifolia Linn., an endemic fruit plant in the upper north of Thailand. The J. Interdiscip. Networks., 2(1): 156-160.

\section{How to cite this article:}

Utpal Barua, R. P. Das, R. K. Bhattacharyya, Priyanka Das, R. N. Sarmah, K. Das and Bornali Gogoi. 2021. Characterization of Nutritional and Physico-chemical Properties of Parameria polyneura Hk.f. Int.J.Curr.Microbiol.App.Sci. 10(01): 2162-2173.

doi: https://doi.org/10.20546/ijcmas.2021.1001.248 